Jurnal Anifa: Studi Gender dan Anak

Volume 2 No. 2, (November 2021) 98-110

P ISSN 2745-7648 | E ISSN 2745-763X

DOI: $10.32505 /$ anifa.v2i1.2902

https://journal.iainlangsa.ac.id/index.php/anifa/index

\title{
PHATIC COMMUNICATION: PSIKOLOGI KOMUNIKASI DALAM PEMBERITAAN ATTA-AUREL DI PORTAL KOMPAS
}

\author{
Ulfa Khairina \\ Institut Agama Islam Negeri (IAIN) Teungku Dirundeng Meulaboh Aceh, \\ Indonesia \\ ulfakhairina@staindirundeng.ac.id
}

\begin{tabular}{ccc}
\hline Received & Revised & Accepted \\
June 07, 2021 & November 15, 2021 & November 30, 2021 \\
\hline
\end{tabular}

\begin{abstract}
Phatic communication is created from effective communication, especially from the pleasure characteristics that arise from communication feedback. Communication is done with a psychological approach in generally liked by netizens (communicants), those presented in online media. This study examines how psychological communication provides feedback from the communicator to the communicant, especially if the source of the news published is an entertainment figure. This study uses descriptive analysis techniques with data collection techniques for Kompas news documentation about Aurel's miscarriage in May 2021. From the results of the study it was found that the news broadcast by Kompas reaped pros and cons for netizens because of writing that used a communication psychology approach. the use of communication psychology raises phatic communication between communicants and communicators.
\end{abstract}

Keywords: Communication, Communication Psychology, Online Media, Kompas, YouTube

\begin{abstract}
Abstrak
Komunikasi fatis tercipta dari komunikasi yang efektif, terutama dari ciri kesenangan yang timbulkan dari umpan balik komunikasi. Komunikasi yang dilakukan dengan pendekatan psikologi umumnya disukai oleh netizen (komunikan), terutama yang disajikan di media online. Penelitian ini mengkaji bagaimana komunikasi psikologi memberikan umpan balik dari komunikator kepada komunikan, terutama jika sumber berita yang dipublikasikan adalah tokoh hiburan. Penelitian ini menggunakan teknik analisis deskriptif dengan teknik pengumpulan data dokumentasi berita Kompas tentang Aurel keguguran pada bulan Mei 2021. Dari hasil penelitian ditemukan bahwa berita yang ditayangkan oleh Kompas menuai pro dan kontra untuk netizen karena penulisan yang menggunakan pendekatakan psikologi komunikasi. penggunaan psikologi komunikasi memunculkan komunikasi fatis antara komunikan dan komunikator.
\end{abstract}

Kata Kunci: Komunikasi Fatis, Psikologi Komunikasi, Media online, Kompas, YouTube. 


\section{PENDAHULUAN}

Kemunculan internet bukan saja memberi kemudahan bagi masyarakat dalam mengakses informasi, tetapi juga mengharuskan media yang terbit secara tradisional berpindah ke sistem digital. Tidak terkecuali bagi media cetak yang beroplah besar juga harus berpindah ke sistem digital yang dikenal dengan media online. Secara keseluruhan, informasi yang diberikan oleh media online cenderung cepat dibandingkan dengan media cetak seperti sebelumnya.

Meskipun berubah nama, media online masih disebut sebagai bagian dari komunikasi massa. Media online juga menggunakan kaidah jurnalistik dalam proses penyebaran informasi dengan karakteristik media yang berbasis teknologi, berkarakter fleksibel, berpotensi interaktif, berfungsi secara privat dan publik, memiliki aturan yang rendah, dan berhubungan (Rumanti, 2002).

Karakter media online yang tersebut di atas memudahkan para pencari informasi dalam mengakses pemberitaan yang diinginkannya, termasuk pemberitaan yang berfungsi memberikan hiburan seperti informasi tentang selebriti. Trend mengagumi selebriti sudah menjadi hal yang lumrah bagi pembaca media online sehingga setiap media nasional bertiras besar seperti Kompas juga mengikuti perkembangan tokoh publik yang diinginkan oleh pembaca muda.

Sejak kemunculan sosial media sebagai pendukung dari media online, Atta Halilintar dikenal sebagai ikon baru idola anak muda karena gaya hidup yang glamor. Popularitas Atta juga meningkat seiring dengan peningkatan jumlah pelanggan di kanal YouTube yang sudah mencapai 27,6 juta pelanggan. Hal ini menunjukkan bahwa pamor Atta Halilintar sebagai YouTuber sangat menginspirasi bagi pengikutnya. Akan tetapi, pro kontra muncul ketika Atta menikah dengan Aurel Hermansyah. Unggahan daily vlog berupa kehidupan rumah tangga Atta_Aurel menjadi konsumsi publik.

Sebagaimana media tradisional yang memberi akses informasi kepada masyarakat, media online juga melakukan hal yang sama dalam pemenuhan hak informasi khalayak. Fitur-fitur unik yang dimiliki oleh media online menawarkan proses dan menyebarkan berita (Santaka K, 2017).

Pada pencarian Kompas, ditemukan sebanyak 265 ribu lebih berita tentang Atta-Aurel dengan berbagai jenis informasi. Hal ini menandakan pasangan baru ini sangat menarik perhatian publik. Pertentangan dari publik justru muncul di bulan Mei 2021 ketika Aurel Hermasyah (istri Atta Halilintar) mengalami keguguran. Konten-konten yang berkaitan dengan keguguran dan kesedihan Aurel menjadi konsumsi publik. Sama halnya seperti yang dilakukan oleh media online lain, Kompas juga mengangkat berita yang sama.

Pemberitaan tentang kehamilan dan keguguran Aurel di media justru 
memberikan dampak psikologi sosial yang buruk untuk Aurel. Meskipun seorang tokoh publik, pembahasan hal sensitif sebagai konsumsi publik tetaplah hal yang negatif. Hujatan dari pembaca tentang konten Atta-Aurel membuktikan bahwa netizen peduli pada psikologi komunikasi yang dicerminkan oleh Aurel di media.

Sesuai dengan definisi yang diungkapkan oleh Kaufmann, psikologi sosial adalah usaha untuk memahami, menjelaskan, dan meramalkan bagaimana pikiran, perasaan, dan tindakan individu dipengaruhi oleh apa yang dianggapnya sebagai pikiran, perasaan, dan tindakan orang lain (yang kehadirannya boleh jadi sebenarnya, dibayangkan, atau disiratkan) (Rakhmat, 2018).

Hal ini sesuai dengan beberapa judul berita yang dimuat oleh Kompas di bulan Mei 2021. Pada 24 Mei 2021, Kompas memuat berita berujudul "Konten Keguguran Aurel Atta Banjir Kritik, Ahli Media LIPI Nilai Wajar". Berita ini memuat tentang pandangan netizen tentang kesempatan yang diambil oleh Atta, keluarga Halilintar, dan keluarga Anang yang mencari keuntungan dari musibah yang dialami oleh Aurel. Hujatan yang ditujukan kepada Atta-Aurel dinilai oleh Lembaga Ilmu Pengetahuan Indonesia (LIPI) sebagai hal yang wajar. Sejak dulu masyarakat ingin mengetahui kehidupan tokoh-tokoh tersebut karena dianggap memiliki dampak untuk dirinya. Meskipun dinilai wajar, dari sudut pandang komunikasi psikologi yang diberitakan oleh media online memiliki kondisi yang berbeda. Media mengendalikan kondisi pesan yang disampaikan oleh tokoh hiburan dalam seluruh informasi tentang AttaAurel kepada masyarakat. Dari pemberitaan tersebut, penulis tertarik mengkaji bagaimana media online memberitakan informasi Atta-Aurel dalam sudut penggunaan psikologi komunikasi.

\section{METODE}

Penelitian ini menggunakan pendekatan kualitatif, yaitu penelitian yang dapat menelaah secara langsung hubungan peneliti dengan objek penelitian. Dalam proses penelitiannya juga akan memermudah peneliti dalam mengkaji pola-pola yang muncul di lapangan (Bungin, 2017). Teknik yang dilakukan dalam proses pengumpulan data menggunakan dokumentasi dengan teknik analisis data model analitis deskriptif, yaitu peneliti akan menuliskan uraian data temuan berdasarkan hasil temuan pada sumber data (Bungin, 2007). Dokumentasi yang akan diteliti adalah artikel yang dimuat di portal Kompas selama bulan Mei 2021 yang berkaitan dengan Atta-Aurel, khususnya terkait berita keguguran Aurel Hermansyah. Penulis menemukan 6 (enam) berita yang 
terkait dengan Atta-Aurel sesuai dengan topik yang akan dikaji.

\section{HASIL DAN PEMBAHASAN}

Kompas.id merupakan media daring yang memuat informasi yang sama dengan versi cetak. Kompas.com dan kompas.id adalah dua institusi yang berbeda. Kompas berbasis di Jakarta dengan slogan amanat hati nurani rakyat.(Ardianto, Elvinaro \& Erdiyana, 2005). Kompas yang berbentuk daring termasuk ke dalam media online. Selain membahas berbagai hal seperti layaknya media cetak, Kompas juga memberitakan hal-hal yang sifatnya hiburan seperti berita Aurel Hermansyah yang mengalami keguguran. Dari sisi Psikologi Komunikasi, berita Atta-Aurel dapat dikaji sebagai berikut.

\section{Hambatan Psikologis Atta-Aurel di Media Online}

Sebagaimana diketahui, media online memberikan informasi lebih cepat dari media cetak. Selain mudah didapatkan oleh pembaca, media online menghubungkan pembaca dengan berita terkait lain yang mempermudah pembaca mendapatkan informasi sejenis. Apalagi pemberitaan tokoh publik di dunia hiburan sangat dekat dengan keingintahuan pembaca. Salah satu tingkatan dalam sistem komunikasi dalam masyarakat sosial adalah sistem komunikasinya. Komunikasi massa berperan serta dalam memahami organisasi kelompok masyarakat yang kompleks. Seiring dengan pertumbuhan masyarakat modern dalam kebutuhan informasi dan hiburan, media semakin dapat diandalkan di dalam masyarakat modern. Isyarat penggunaan alat-alat mekanis dan elektronis juga dipakai untuk mencapai tujuan dari sistem komunikasi (Effendy, 1989).

Sistem informasi berupa hiburan yang dibaca oleh masyarakat melalui media online mempengaruhi kehidupan para selebriti untuk membangun citra diri di dalam masyarakat. Pembangunan citra diri umumnya dibangun oleh media-media besar yang akan mengangkat nama mereka menjadi bintang besar. Tidak terkecuali mengekspos kehidupan pribadi para selebriti seperti Atta-Aurel.

Komunikasi massa memiliki tingkatan dalam penciptaan karakter dan ekploitasi kehidupan pribadi selebriti seperti Atta-Aurel. Terlebih lagi media online seperti Kompas akan sangat mempengaruhi personal branding yang mereka bangun. Kehidupan Aurel Hemansyah yang disorot oleh Kompas memberikan gambaran pada pembaca bahwa Aurel memiliki hambatan psikologis dalam menghadapi kehidupannya. Sebutan hambatan psikologis mengacu pada hambatan tersebut merupakan unsur-unsur dari kegiatan psikis 
manusia (Ardianto, Elvinaro \& Erdiyana, 2005). Ada 4 (empat) hambatan psikologis dalam komunikasi massa, termasuk di dalamnya media online. Keempatnya adalah kepentingan (interest), prasangka (prejudice), steorotip (steorotype), dan motivasi (motivation). Keempat hamabatan psikologis ini terlihat dari pemberitaan Kompas tentang peristiwa yang dialami oleh Aurel Hermansyah.

Dari sisi kepentingan (interest), komunikan akan selektif dalam menanggapi atau menghayati pesan. Kepentingan komunikan dalam suatu kegiatan komunikasi sangat ditentukan oleh manfaat atau kegunaan pesan komunikasi itu bagi dirinya. Hal ini menggambarkan bahwa kepentingan juga mempengaruhi sifat reaktif komunikan terhadap pesan komunikasi yang diterimanya (Ardianto, Elvinaro \& Erdiyana, 2005).

Berita berjudul "Berkaca Dari Konten Atta-Aurel Soal Keguguran, Sikap Kritis Netizen Dibutuhkan" yang dipublikasikan di Kompas pada tanggal 25 Mei 2021. Dari segi judul berita, artikel ini jelas memuat kepentingan (interest) komunikan dalam memanfaatkan berita. Tokoh yang dimaksud dalam berita tersebut juga memiliki kepentingan terhadap komunikan yang mengkritisi mereka.

Dalam berita ini (Kompas, 2021), kalimat diawali dengan komentar Sosiolog terhadap konten Atta-Aurel di dunia maya. Sikap kritis netizen terhadap konten yang diproduksi oleh Atta-Aurel akan mempengaruhi daya pikir komunikan, khususnya berkaitan dengan manfaat dan kegunaan untuk komunikan pribadi. Dalam hal ini, netizen memiliki kemampuan mengontrol dalam menyeleksi berita yang diterima. Adanya pro kontra dari netizen akan terjadi proses ilmiah mengedukasi masyarakat. Sesuai dengan fungsinya sebagai salah satu bagian dari komunikasi massa, media daring juga merupakan sarana bagi khalayaknya (mass education). Karena media banyak menyajikan hal-hal yang sifatnya mendidik (Ardianto, Elvinaro \& Erdiyana, 2005). Begitupun dengan pemberitaan yang dipublikasikan di Kompas tersebut, Sosiolog mengkritisi konten yang diciptakan oleh Atta-Aurel. Kalimat yang merujuk pada kepentingan (interest) komunikan dalam melakukan seleksi dalam pemilihan berita dan terjadinya umpan balik terhadap pemberitaan dapat dilihat pada kalimat berikut ini:

"Seperti diketahui, berita keguguran yang dialami Aurel sempat menuai simpati publik. Namun, kini Atta justru menjadi sorotan setelah konten-konten terkait Aurel keguguran terus tayang."

Kehadiran Sosiolog dalam berita tersebut merupakan cara Kompas untuk mengklarifikasi pro kontra netizen (komunikan) yang memiliki prasangka (prejudice). Prasangka (prejudice) merupakan salah satu bagian dari hambatan psikologi yang terlahir dari persepsi. Prasangka berkaitan dengan persepsi 
orang tentang seseorang atau keompok lain, dan sikap serta perilakunya terhadap mereka (Ardianto, Elvinaro \& Erdiyana, 2005).

Persepsi komunikan yang dimunculkan di media berkaitan erat dengan faktor personal dan situasional. Pemberitaan keguguran Aurel yang disorot media sempat menjadi simpati kemudian terlahir sebagai kritik. Hal ini disebabkan oleh simpati awal oleh faktor personal karena Aurel adalah seorang tokoh publik yang cukup disorot. Kemudian situasi yang dimanfaatkan oleh Atta menjadikan masalah sensitif keluarga menjadi konten untuk mencari uang menjadi masalah yang berbeda dan memunculkan kontra dalam masyarakat.

Prasangka yang diberikan oleh komunikan dalam berita ini juga diwakilkan oleh salah satu publikasi di Kompas pada 24 Mei 2021 dengan judul berita "Konten Keguguran Aurel Atta Banjir Kritik, Ahli Media LIPI Nilai Wajar." Pada berita ini, Kompas juga memilih seorang peneliti dari LIPI untuk menjadi narasumbernya. Sehingga berita yang ditulis oleh Kompas tidak hanya memuat satu sisi saja, tetapi dari kedua sisi.

Kompas sebagai komunikator menghindari prasangka komunikan dengan narasumber yang menjadi komunikator untuk kasus Aurel mempunyai reputasi baik. Artinya komunikator yang dipilih oleh Kompas untuk memberi wacana tidak terlibat dalam peristiwa yang dialami Aurel, yaitu bukan pihak dari keluarga Gen Halilintar, keluarga Anang ataupun Atta-Aurel sendiri. Prasangka seringkali tidak didasarkan pada alasan yang objektif, sehingga prasangka tidak didasarkan pada logis dan tidaknya suatu pesan atau manfaat pesan itu bagi diri komunikan melainkan menentang pribadi komunikator (Ardianto, Elvinaro \& Erdiyana, 2005). Dalam berita ini, penulis berita mengutip komentar-komentar netizen (komunikan) tentang kritik terhadap Atta-Aurel. Prasangka yang dilontarkan oleh netizen (komunikan) di sosial media menjadi sorotan Lembaga Ilmu Pengetahuan Indonesia (LIPI) dan menjadi bahasan ilmiah. Apa yang terjadi dengan Aurel Hermansyah dikaitkan dengan sejarah pada tahun 1970-an tentang kehidupan pribadi Aristotle Onasis yang disorot oleh publik, baik terkait bisnisnya ataupun kisah cintanya (Kompas, 2021). Dari penilaian tersebut dapat disimpulkan bahwa prasangka yang ditujukan untuk Atta-Aurel sama dengan apa yang pernah terjadi pada sejarah tokoh publik sebelumnya.

Prasangka melahirkan stereotip (stereotype) di kalangan komunikan terhadap komunikator. Stereotip terjadi karena adanya gambaran tertentu mengenai sifat_sifat dan watak pribadi atau golongan lain yang negatif. Dalam proses komunikasi yang dilakukan oleh Kompas tentang Aurel Hermansyah, Kompas tidak menciptakan stereotip terhadap pesan yang disampaikan melalui berita-berita yang dipublikasikan di bulan Mei 2021. 
Kemunculan kepentingan, prasangka, dan stereotip tidak dapat dipisahkan dari adanya motivasi (motivation). Setiap komunikan yang mengikuti pemberitaan Aurel Hermansyah keguguran di media online didasarkan oleh motif tertentu. Setiap komunikan memiliki motif berbeda mengenai berita Aurel Hermansyah. Akan tetapi masih ada kesamaan motif yang sama antara satu komunikan dengan komunikan lainnya, yaitu kebutuhan informasi tentang tokoh publik yang disukainya.

\section{Perbedaan Pemilihan Komunikasi Verbal Penulis Kompas}

Penggunaan psikologi komunikasi di Kompas tidak hanya didasarkan pada Atta-Aurel dan keguguran yang dialami Aurel sebagai nilai berita. Gaya penulisan yang disajikan berdasarkan nilai berita juga mempengaruhi psikologi komunikan pada umumnya. Media online yang memiliki kecepatan penyebaran berita lebih cepat dari berita cetak mengharuskan penulis memiliki keterampilan khusus dalam merangkai diksi dalam penulisan berita. Selama bulan Mei 2021, terdapat 6 (enam) berita yang membahas tentang Aurel keguguran. Sebanyak 3 (tiga) berita ditulis oleh laki-laki dan 3 (berita ditulis oleh perempuan. Keenam berita yang dipublikasikan oleh Kompas memiliki perbedaan dari segi pelibatan emosional dalam bahasa verbal yang disajikan oleh penulis. Meskipun keenam artikel memiliki kecenderungan nilai berita tokoh publik, keenamnya memiliki ciri khusus komunikasi verbal yang ditonjolkan. Penulis wanita dan pria memiliki ciri khas dalam penulisan berita tentang Aurel keguguran.

Bahasa pria dan wanita mempunyai kosakata yang berlainan. Saah satu penyebanya adalah sosialisasi mereka yang berbeda, khususnya minat terhadap aspek kehidupan. Deborah Tannen mengatakan wanita cenderung menata pembicaraan secara kooperatif, sedangkan pria cenderung menatanya secara kompetitif. Terdapat juga perbedaan pragmatik antara pria dan wanita dalam mengungkapkan komunikasi verbal. Wanita menggunakan lebih banyak pembicaraan ekspresif (untuk menyatakan emosi). Sedangkan pria menggunakan lebih banyak pembicaraan instrumental (untuk mempengaruhi dan mengendalikan orang lain), melaporkan informasi, memecahkan masalah, dan menyelesaikan tugas pertukaran informasi (Mulyana, 2017). Dari segi judul, penulis wanita cenderung menggunakan sisi emosi untuk menggambarkan keseluruhan isi yang dipaparkan dalam berita. Selain menggunakan fakta, penulis wanita juga menyisipkan kata_kata yang berbalut emosi untuk menggambarkan kondisi Aurel.

Kesedihan Aurel dan Atta Terpaksa Kubur Punya Anak Cepat yang ditulis oleh Melvina Tionardus memberitakan tentang apa yang dirasakan oleh Aurel 
Hermansyah, termasuk di dalamnya mengisahkan kronologis yang menyebabkan keguguran. Selain penulisan lebih deskriptif, penulis juga mengutip beberapa unggahan Aurel dan Atta di Instagram yang berkaitan dengan keguguran Aurel.

Berita yang dipublikasikan pada tanggal 19 Mei 2021 ini ditulis dengan beberapa pilihan sub judul yang menyentuh seperti Sampai Jumpa di Surga, Berharap Didoakan Anak, Kehilangan dan Gantinya, dan Aurel Nangis Cerita Keguguran. Berita yang ditulis oleh Melvina Tionardus ini mengarah kepada psikologi komunikasi Aurel dalam mengungkapkan kesedihannya kepada media.

Berita yang dipublikasikan pada tanggal 15 Mei 2021 dengan judul Aurel Sempat pendarahan, Atta Halilintar Lebih Galak dan Larang Joget Tik Tok ditulis oleh Rintan Puspita Sari. Meskipun isi berita yang ditulis oleh Rintan Puspita Sari sangat pendek, tapi keseluruhan emosi dan sisi melankolis ditonjolkan dalam berita ini. kepedulian Atta terhadap Aurel lebih ditonjolkan dalam penulisan berita yang ditulis oleh Rintan Puspita Sari.

Sedangkan berita yang ditulis oleh Gloria Setyvani Putri dengan judul Konten Keguguran Aurel Atta Banjir Kritik, Ahli Media LIPI Nilai Wajar lebih mendekati pendekatan psikologis penulis dalam memberi dukungan kepada Aurel Hermansyah dengan menghadirkan narasumber terpercaya. Dalam berita ini penulis menunjukkan kepada komunikator bahwa mereka bukan satu-satunya yang mengalami hal tersebut. Pembelaan lain juga disorot pada netizen (komunikan) yang mengkritisi tindakan mereka dan penulis mengaitkan dengan sejarah pada Aristotle Onasis yang juga seorang tokoh publik.

Berbeda dengan penulis wanita yang cenderung melibatkan perasaan ketika menulis, penulis pria lebih mengedepankan analisis yang mempengaruhi dan mengendalikan orang lain. Dalam hal ini penulis pria menulis artikel untuk mempengaruhi dan mengendalikan netizen (komunikan) Kompas.

Berita yang ditulis oleh Vincentius Mario pada tanggal 13 Mei 2021 dengan judul Aurel Sedih Rayakan Lebaran, Atta Ungkap Kondisi Sang Istri berisi ketegasan di dalam judul yang dibuat. Secara keseluruhan, berita yang ditulis oleh Vincentius Mario tidak mendetil dan hanya berisikan kalimat pendek yang mengabarkan Aurel Hermansyah harus melakukan bed rest. Secara umum berita ini bersifat straight news saja. Menurut Kamus Komunikasi (Effendy, 1989), straight news adalah berita surat kabar, radio atau televisi mengenai suatu peristiwa yang terjadi di masyarakat yang disusun secara faktual dan obyektif tanpa opini atau interpretasi si penyusun. Berita singkat yang dipublikasikan di 
media online seperti Kompas dan ditulis oleh Vincentus Mario termasuk dalam jenis straight news.

Penulis pria cenderung menulis dengan gaya straight news, sedangkan penulis wanita memiliki kecenderungan menulis berita dengan gaya soft news. Kedetilan gaya bahasa wanita dibandingkan pria akan lebih banyak menarik minat pembaca dan mengundang simpati netizen (komunikan). Sehingga psikologi dari komunikasi yang dipaparkan oleh Aurel Hermansyah maupun Atta Halilintar dalam setiap postingan di media akan mengundang pro dan kontra, dukungan dan kritik, serta penelitian tahap lanjut.

\section{Psikologi Komunikasi Aurel Hermansyah Kepada Media}

Secara umum, psikologi meneliti tentang kesadaran dan pengalaman manusia. Terutama dalam mengarahkan perhatian manusia terhadap perilaku manusia lainnya dalam melakukan sesuatu. Apa yang terjadi di media Kompas saat publikasi berita tentang Atta-Aurel adalah berkaitan dengan perilaku psikologi. Netizen (komunikan) mengamati perilaku dengan sadar semua pengalaman yang dibagikan oleh Atta-Aurel kepada media dan komunikan

Apa yang dilakukan oleh Kompas mencakup keempat ciri pendekatan psikologi pada komunikasi menurut Fisher, yaitu: penerimaan stimuli secara inderawi (sensory reception of stimuli), proses yang mengantarai stimuli dan respon (internal mediation of stimuli), prediksi respon (prediction of response), dan peneguhan respon (reinforcement ofresponses) (Rakhmat, 2018). Di antara semua ciri yang dipaparkan oleh Fisher, reaksi yang ditimbulkan psikologi dalam komunikasi Aurel Hermansyah kepada media adalah peneguhan respon (reinforcement of responses). Sebagai komunikator, Atta-Aurel memberikan pesan kepada komunikan melalui media dan mendapatkan respons lingkungan secara maksimal. Semua kritik dan dukungan yang silih berganti dan diberitakan berulang oleh Kompas adalah salah satu ciri seperti yang dipaparkan oleh Fisher. Peneguhan merupakan respons lingkungan (atau orang lain pada respons organisme yang asli) (Rakhmat, 2018). Sejauh ini belum ada cakupan psikologi komunikasi Atta-Aurel. Komunikan cenderung melihat hal-hal yang tampak saja dari perilaku Aurel Hermansyah yang dipublikasikan oleh Atta Halilintar.

Sehingga kasus yang terjadi pada Aurel Hermansyah dan dipublikasikan oleh Kompas menggambarkan pengertian psikologi komunikasi berdasarkan pendapat George A. Miller. Menurut George A. Miller (Rakhmat, 2018) psikologi komunikasi adalah ilmu yang berusaha menguraikan, meramalkan, dan mengendalikan peristiwa mental dan behavioral dalam komunikasi. Peristiwa behavioral adalah yang nampak ketika orang berkomunikasi. Dari 
penjabaran definisi di atas, Aurel Hermansyah telah terlibat dalam proses komunikasi dengan melibatkan unsur psikologi dalam tiap aksinya dan pemberitaan di media massa, terutama yang dipublikasikan di Kompas selama bulan Mei 2021.

Kompas melalui berita-beritanya menguraikan segala kejadian yang dialami oleh Aurel Hermansyah dengan sumber utama unggahan Atta Halilintar di sosial media. Kompas juga mampu meramalkan apa yang akan terjadi dan sudah terjadi setelah publikasi Aurel Hermansyah di media dengan mengundang dan melakukan wawancara dengan beberapa ahli. Para ahli yang mengkaji berita dan kasus Aurel Hermansyah di media menjadi salah satu cara Kompas dalam mengendalikan peristiwa mental yang dialami oleh Aurel Hermansyah. Sedangkan peristiwa behavioral terjadi ketika terjadi umpan balik (feedback) dari netizen (komunikan) terhadap komuniator.

\section{Komunikasi Efektif Kompas Dalam Pemberitaan Atta-Aurel}

Penggunaan psikologi komunikasi pada media Kompas juga melibatkan komunikasi yang efektif. Kompas menyeragamkan gaya bahasa yang bisa diterima oleh masyarakat Indonesia yang heterogen. Latar belakang pembaca Kompas berasal dari berbagai latar belakang dengan gaya bahasa yang berbeda, sehingga penerimaan antar bahasanya juga akan berbeda-beda pula. Kecenderungan yang dipakai oleh Kompas dalam pemberitaan Atta-Aurel menggunakan komunikasi konteks-tinggi, yaitu komunikasi yang mengandung pesan yang kebanyakan terdapat konteks fisik, sehingga makna pesan hanya dapat dipahami dalam konteks tersebut (Mulyana, 2017). Dalam berita AttaAurel, makna yang terinternalisasikan pada orang yang bersangkutan. Kompas menekankan dan memfokuskan isi berita pada Aurel Hermansyah dan Atta Halilintar. Meskipun kompas memaparkan banyak pesan verbal, tetapi secara tidak langsung juga menyiratkan pesan nonverbal melalui foto yang sama dijadikan sebagai ilustrasi pendukung.

Dari 6 (enam) berita yang digunakan oleh Kompas sebagai ilustrasi pendukung berita, kebanyakan foto yang digunakan adalah foto Aurel yang disuapi oleh Atta Halilintar. Foto ini memberikan nilai komunikasi noverbal untuk mendukung komunikasi secara verbal konten berita yang dipublikasikan oleh Kompas. Sementara itu, netizen (komunikan) Kompas banyak yang menanggapi berita Atta-Aurel dengan komunikasi konteks-rendah. Hal ini dapat ditandai dari dukungan dan kritik yang diberikan oleh komunikan kepada Atta-Aurel, terutama di awal Aurel Hermansyah keguguran.

Komunikasi konteks-rendah cepat dan mudah berubah, karenanya juga tidak mengikat kelompok. Netizen (komunikan) bisa berubah penilaian kepada 
Atta_Aurel dalam waktu singkat. pemberian simpati dan ungkapan belasungkawa atau keguguran Aurel di sosial media juga menuai kritik setelahnya. Seperti yang diberitakan oleh Kompas, kritikan yang dilakukan oleh netizen juga sempat menjadi bahan kajian Lembaga Ilmu Pengetahuan Indonesia (LIPI). Terjadinya pro dan kontra terhadap Atta-Aurel aksi dan pandangan kelompok masyarakat. ketidakterikatan konsep komunikasi yang terjadi di kelompok masyarakat menunjukkan adanya komunikasi konteksrendah.

Keberadaan komunikasi konteks-tingi dan komunikasi konteks-rendah juga bagian dari komunikasi efektif. Menurut Stewart L. Tubbs dan Sylvia Moss (Rakhmat, 2018), komunikasi yang efektif akan menimbulkan 5 (lima) hal: pengertian, kesenangan, pengaruh pada sikap, hubungan makin baik, dan tindakan. Kelima hal tersebut timbul dari berita Atta-Aurel di Kompas dan netizen (komunikan). Artinya Kompas memiliki komunikasi efektif dalam menggunakan pendekatan psikologi saat menyampaikan pesan berkaitan dengan Atta-Aurel.

\section{Komunikasi Fatis (Phatic Communication) Untuk Kesenangan Pembaca}

Komunikasi fatis (phatic communication) muncul dari ciri yang ditimbulkan oleh komunikasi yang efektif, yaitu ciri yang menimbulkan kesenangan. Tidak semua komunikasi yang dihadirkan dan dimunculkan untuk membentuk pengertian (Rakhmat, 2018). Kompas sebagai media nasional bertiras dan traffic tinggi memiliki komptensi untuk menimbulkan kelima komunikasi yang efektif dengan netizen (komunikan). Tidak semua berita yang ditayangkan oleh kompas melalui media online memberikan kesenangan dan pengertian. Beberapa rubrik yang disajikan oleh Kompas memberikan efek sebaliknya. Namun pemberitaan yang berkaitan dengan tokoh hiburan selalu memberikan kesenangan untuk komunikan. Baik ditanggapi dengan positif atau negatif, pemberitaan tentang tokoh hiburan akan selalu memberikan kesenangan pada komunikan.

Komunikasi fatis menyebabkan hubungan menjadi hangat dan akrab. Hubungan komunikan dengan media (komunikator) akan menjadi hangat jika media tersebut mampu memberitakan informasi yang menyenangkan. Terutama informasi atau berita yang erat kaitannya dengan keinginan pembaca. Pembaca menginginkan berita tentang tokoh yang diinginkan lebih banyak dan beragam. Berita yang beragam dari berbagai sisi akan memberikan kesenangan untuk komunikan.

Atta Halilintar dan Aurel Hermansyah merupakan pasangan baru yang memiliki pengikut setia karena konten mewah yang mereka ciptakan. 
Kehidupan pribadi Atta-Aurel setelah menikah tidak ditutupi dari publik. Keinginan komunikan untuk selalu mengetahui kehidupan tokoh yang disenangi mampu dipenuhi oleh Kompas melalui pemberitaan yang beragam. Selama bulan Mei 2021, 6 (enam) berita yang dipublikasikan Kompas sudah cukup memberikan kesenangan untuk komunikan dengan jenis pendekatan yang beragam. Ragam pemberitaan Atta-Aurel terkait dengan keguguran Aurel Hermasyah menjadi topik yang dominan disukai oleh komunikan.

Jadi, komunikasi fatis dapat diberikan oleh media (komunikator) kepada komunikan dengan menghadirkan tokoh publik yang berkaitan dengan dunia hiburan untuk memberikan kesenangan pada komunikan. Komunikasi fatis yang diberikan oleh Kompas kepada komunikan berupa pemberitaan AttaAurel dengan menggunakan pendekatan psikologi.

\section{KESIMPULAN}

Komunikasi fatis merupakan salah satu ciri yang ditimbulkan dari komunikasi efektif, yaitu timbulnya hal menyenangkan dari umpan balik komunikasi yang terjadi. Komunikasi fatis bisa diciptakan dalam komunikasi tatap muka juga komunikasi massa. Dalam komunikasi massa, komunikasi fatis terjadi dengan adanya berita-berita yang membuat komunikan senang setelah membacanya. Salah satunya adalah pemberitaan Atta-Aurel. Meskipun selama bulan Mei 2021 pemberitaan tentang Atta-Aurel di Kompas berikan berita duka, tetapi komunikan menyukai berita-berita tersebut dengan gaya komunikasi konteks-rendah dan komunikasi konteks-tinggi. Penulis berita juga memberi pengaruh dalam menciptakan komunikasi fatis antara komunikator dan komunikan. Penulis pria cenderung menggunakan bahasa yang praktis dan penulis wanita cenderung melibatkan emosi. Perbedaan antara penulis pria dan wanita menciptakan ragam komunikasi dengan pendekatan psikologi. Selama bulan Mei 2021, media online Kompas berhasil menimbulkan komunikasi yang efektif dengan pendekatan ciri memberikan kesenangan kepada komunikan, yaitu memunculkan komunikasi fatis pada komunikan. Komunikan yang dimaksud di sini adalah netizen yang mengikuti semua berita tentang Aurel Hermansyah dan Atta Halilintar.

\section{DAFTAR PUSTAKA}

Ardianto, Elvinaro \& Erdiyana, L. K. (2005). Komunikasi Massa Suatu Pengantar. Simbiosa Media Rekatama.

Ardito Ramadhan, "Berkaca Dari Konten Atta-Aurel Soal Keguguran, Sikap Kritis Netizen Dibutuhkan," diakses melalui https://nasional.kompas.com/read 
/2021/05/25/07350431/berkaca-dari_konten-atta-aurel-soal-keguguransikap-kritis-netizen?page=all pada tanggal 3 Juni 2021.

Bungin, B. (2007). Analisis Data Kualitatif. Raja Grafindo Persada.

Bungin, B. (2017). Metodologi Penelitian Kualitatif. PT Raja Grafindo Persada.

Effendy, O. U. (1989). Kamus Komunikasi. Bandung. Mandar Maju.

Gloria Setyvani Putri, “Konten Keguguran Aurel Atta Banjir Kritik, Ahli Media LIPI Nilai Wajar," diakses melalui https://www.kompas.com/sains/read/ 2021/05/24/170300023/konten_keguguran-aurel-atta-banjir-kritik-ahlimedia-lipi-nilai-wajar?page=all pada tanggal 3 Juni 2021.

Kompas (Surat Kabar)" diakses melalui https://id.wikipedia.org/wiki/ Kompas_(surat_kabar) pada tanggal 3 Juni 2021.

Melvina Tiodarnus, "Kesedihan Atta-Aurel Terpaksa Kubur Punya Anak Cepat" diakses melalui https://www.kompas.com/hype/read/2021/05/19/ 092045566/kesedihan-aurel_dan-atta-terpaksa-kubur-mimpi-punyaanak-cepat?page=all pada tanggal 3 Juni 2021.

Mulyana, D. (2017). Komunikasi Efektif, Suatu Pendekatan Lintas Budaya. Remaja Rosdakarya.

Rakhmat, J. (2018). Psikologi Komunikasi. Remaja Rosdakarya.

Rumanti, M. A. (2002). Dasar-Dasar Public Relation: Teori dan Praktik. Gramedia Widia Sarana Indonesia.

Rintan Puspita Sari, “Aurel Sempat pendarahan, Atta Halilintar Lebih Galak dan Larang Joget Tik Tok" diakses melalui https://www.kompas.com/hype/ read/2021/05/15/164009366/aurel-sempat_pendarahan-atta-halilintarlebih-galak-dan-larang-joget-tiktok pada tanggal 3 Juni 2021.

Santaka K, S. (2017). Jurnalisme Kontemporer. Yayasan Pustaka Obor Indonesia.

Vincentius Mario, "Aurel Sedih Rayakan Lebaran, Atta Ungkap Kondisi Sang Istri" diakses melalui https://www.kompas.com/hype/read/2021/05/13/ 112740166/aurel-sedih_rayakan-lebaran-atta-ungkap-kondisi-sang-istri pada 3 Juni 2021 